\title{
Evaluation of machinability of alloy ductile iron in term of thrust drilling force
}

\author{
${ }^{1}$ Hamed Tanabi \\ ${ }^{1}$ Department of Mechanical Engineering, University of Turkish Aeronautical Association, Ankara, Turkey
}

\begin{abstract}
The main aim of this work is the assessment of the machinability of alloyed ductile iron before the austempering process. $16 \mathrm{MnCr} 5$ alloy steel and alloyed ductile specimens were subjected to drilling tests. The effect of drilling parameters on cutting force was investigated based on the Taguchi approach. Based on the results, a regression model was established to predict thrust force at various drilling conditions. The predicted thrust forces ratio was then used to evaluate the machinability of alloyed ductile respect to the $16 \mathrm{MnCr} 5$ alloy steel. The results showed that at lower feed rate, the normal drilling force is very close for both materials, such that the estimated machinability rating is $86 \%$.
\end{abstract}

Keywords: Alloy Ductile Iron, Austempered Ductile Iron, cutting force, Taguchi Method

\section{Introduction}

The properties such as lower production costs, high strength to weight ratio, high wear resistance, good fatigue strength, and the ability to produce components with complex shapes, introduce the austempered ductile iron (ADI) as an attractive alternative to forging and casting steels [1]. The evaluation of the components capable of being manufactured from ADI is one of the issues that has been of great interest to the manufacturers of cast iron parts. In this regard, the number of steel parts replaced by ADI is added gradually. In 1976, General Motors Company replaced forged steel ring gear and hypoid pinion with ADI material [2]. In the same years, Ford Company manufactured rear axle bevel gears using ADI as a replacement for forged steel [2]. In 1987, Ford Motor Company replaced forged steel crankshafts with ADI ones for diesel engines [3].

The mechanical properties of ADI have been investigated in several studies [4-8]. Refaey and Fatahalla [9] compared the toughness, wear characteristics, and mechanical properties of ADI and low alloyed ductile iron with conventional ductile iron. The results of this study showed that the hardness, strength, and wear resistance of ADI is much greater than conventional ductile iron. In another study, Lerner and Kingsbury [10], found that wear resistance of ADI is four times, 12 times, and 14 times greater than pearlite ductile iron, leaded-tin bronze, and aluminum bronze, respectively.

Despite remarkable mechanical properties, the main concern is the machinability of ADI due to its high hardness and strength [11]. Machinability is the degree of difficulty of machining of material under specified machining conditions and can be evaluated based on tool life, cutting forces, or workpiece surface finish quality under the same cutting conditions [12].

*Corresponding author: Department of Mechanical Engineering, University of Turkish Aeronautical Association, Ankara, TURKEY. E-mail address: htanabi@thk.edu.tr 
In literature, the low machinability of the alloy ductile iron and ADI is referred to as the morphology, alloying elements, and phase transformation during machining operation $[5,13,14]$. Alloying elements such as molybdenum, nickel, manganese, and copper are used to increase the hardenability of the final ADI. Among these elements, carbide-forming elements such as molybdenum and manganese tend to segregate toward cell boundaries during the casting process. These carbides are detrimental to the machinability and tool life [14].

Phase transformation during the machining is another issue which results in a significant reduction in tool life $[13,14]$. The austenite on the surface undergoes a strain-induced transformation to martensite, which is harder and more brittle than the ausferrite structure.

This paper presents the machinability test results of a project undertaken to replace forged steel Ring Gear of ITM-285 two wheels tractor with ADI. To be more specific, machinability of the alloyed ductile iron is compared with normalized $16 \mathrm{MnCr} 5$ steel.

\section{Materials and Method}

\subsection{Manufacturing process of Ring Gear}

The manufacturing process of the Ring Gear made by $16 \mathrm{MnCr} 5$ alloy steel and ADI are illustrated in Figure 1. Various machining operations were carried out on normalized forged or as-cast alloyed ductile iron Ring Gear specimens. After machining, the hardness of the forged steel and ductile iron Ring Gears is increased by carburizing and austenitizing heat treatments, respectively.

\subsection{Microstructure characterization}

For metallography study, test specimens were cut from keel block castings. Test specimens were then polished. An optical microscope was used to study the microstructure of the un-etched and etched (2\% nital) samples. The metallography study was also done on austempered samples.

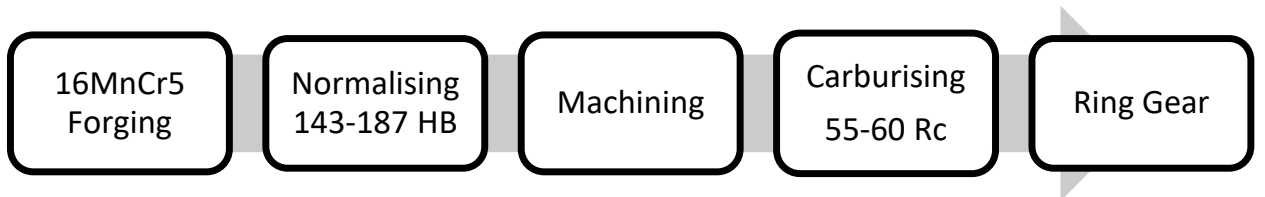

(a)

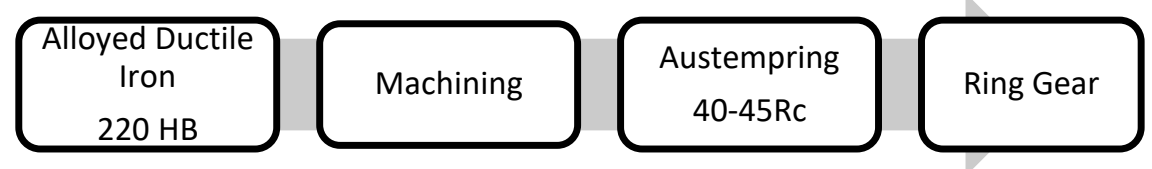

(b)

Figure 1 Manufacturing process of Ring Gear from, a) 16MnCr5 alloy steel, b) ADI 


\subsection{Machinability tests}

In this study, the evaluation of machinability is carried out in terms of the thrust cutting force in the drilling operation. Drilling experiments were carried out using universal vertical milling. SECO SD203A-9.5-29-10R1-N drill tool was used. Tests were performed in dry cutting conditions. The cutting force during drilling was used as machinability criteria. The vertical drilling force was measured using a load cell (SM600-100kgf by Sewhacnam). In order to eliminate the alignment errors, a die set with low friction guide pillars was used. Both load cell and test specimens mounted on a die set. Measured data were monitored and recorded using Labview software (National Instruments). The experimental set up is shown in Figure 2.

Ductile Iron (DI) samples were cast in cylindrical form diameter of $75 \mathrm{~mm}$ and length of $65 \mathrm{~mm}$. DI samples were then sized to cylinders of $70 \mathrm{~mm}$ diameter and $60 \mathrm{~mm}$ length. Also, cylinders of $40 \mathrm{~mm}$ diameter and $40 \mathrm{~mm}$ length were prepared from normalized forged steel. The chemical composition of the alloy DI and forged samples are given in Table 1.

Taguchi [32] L9 standard orthogonal array was utilized to design the experiments. The statistical software MINITAB 16 was used for the design of experiments as well as the statistical analysis of the results. Ranges of process parameters and their corresponding levels are presented in Table 2.

Table 1 Chemical composition of the 16MNCR5 and alloyed DI

\begin{tabular}{cccccccc}
\hline & $\% \mathrm{C}$ & $\% \mathrm{Si}$ & $\% \mathrm{Mn}$ & $\% \mathrm{Cu}$ & $\% \mathrm{Cr}$ & $\% \mathrm{Ni}$ & $\% \mathrm{Mo}$ \\
\hline 16MNCR5 & 0.16 & 0.4 & 1.1 & 0.27 & 1.1 & - & - \\
ADI & 3.6 & 2.41 & 0.33 & 0.65 & 0.02 & 0.7 & 0.3 \\
\hline
\end{tabular}

Table.2 Experimental factors and levels

\begin{tabular}{ccc}
\hline \multirow{2}{*}{ Level } & \multicolumn{2}{c}{ Factors } \\
\cline { 2 - 3 } & $\mathrm{n}(\mathrm{rpm})$ & $\mathrm{f}(\mathrm{mm} / \mathrm{min})$ \\
\hline 1 & 400 & 100 \\
2 & 500 & 125 \\
3 & 600 & 160 \\
\hline
\end{tabular}

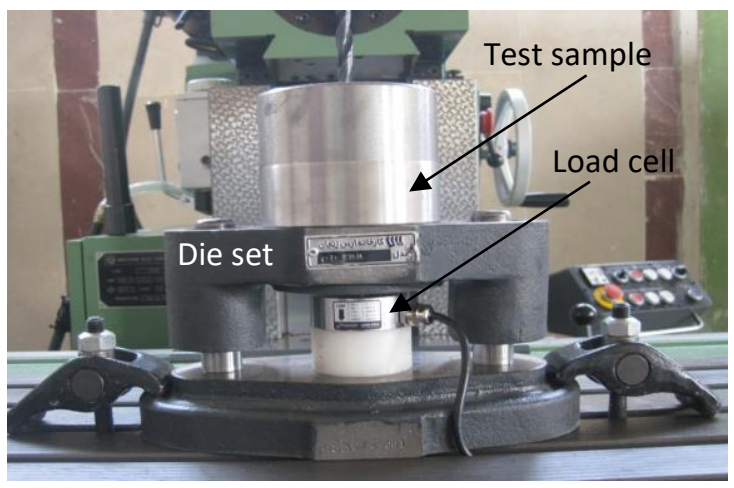

Figure 2. Machinability test set up 


\section{Results}

\subsection{Material characterization}

As-cast structure of ductile iron is shown in Figure 3a. The structure consists of embedded graphite nodules in ferritic envelop with a pearlitic matrix. Characterization of the microstructure in accordance with ASTM A247-67 shows that the shape and density of the graphite in the microstructure is classified as type II (5-7). The microstructure of the ADI specimen is shown in Figure $3 \mathrm{~b}$. It can be noticed in Figure $3 \mathrm{~b}$ that the microstructure is an ausferritic microstructure. Retained austenite (white areas) is seen in the microstructure.

\subsection{Machinability tests}

Taguchi approach was used to investigate the machinability of the alloyed ductile iron and normalized forged steel based on the normal during force. Table 3 and Table 4 shows the measured vertical drilling force for each sample set. The effectiveness of the process parameters on the response factor (cutting force) was investigated through ANOVA (Table 5 and Table 6). Considering the calculated P-values, the main factors have a significant effect on drilling cutting force as the calculated $p$-value is less than the significance level threshold $(\alpha=0.05)$. The contour plots of thrust force versus the experimental factors are shown in Figure 4. In all cases, a higher force is consumed for drilling DI comparing normalized forged steel specimens (see Table 3 and Table 4). However, at higher rotational speed, this difference is considerably lower than the observed difference at low speeds. On the other hand, the required load for drilling the normalized $16 \mathrm{MnCr} 5$ steel becomes 1.5 times by increasing the feed rate from 100 to $160(\mathrm{~mm} / \mathrm{min})$. For DI, this rate is around 1.7 .

In order to compare the machinability of alloyed ductile iron with normalized forged $16 \mathrm{MnCr} 5$ steel, the drilling force at various pre-determined cutting conditions is calculated using the fitted regression models. The minimum drilling fore was predicted for drilling of $16 \mathrm{MnCr} 5$ at $n=$ $600 \mathrm{rpm}$ and $f=100(\mathrm{~mm} / \mathrm{min})$. Machinability rating is then calculated using:

$$
M R(\%)=\frac{\left(F_{F S}\right)_{\min }}{F} \times 100
$$

Where $\left(F_{F S}\right)_{\min }$ is the minimum force, which is estimated for drilling of the normalized forged steel specimens. Considering Table 7 , the minimum cutting force in the drilling of normalized forge steel specimens was predicted as $2741 \mathrm{~N}$ where the required force for drilling of the ductile iron specimens is $3170 \mathrm{~N}$ at the same cutting conditions $(n=600 \mathrm{rpm}$ and $f=100(\mathrm{~mm} / \mathrm{min}))$. 


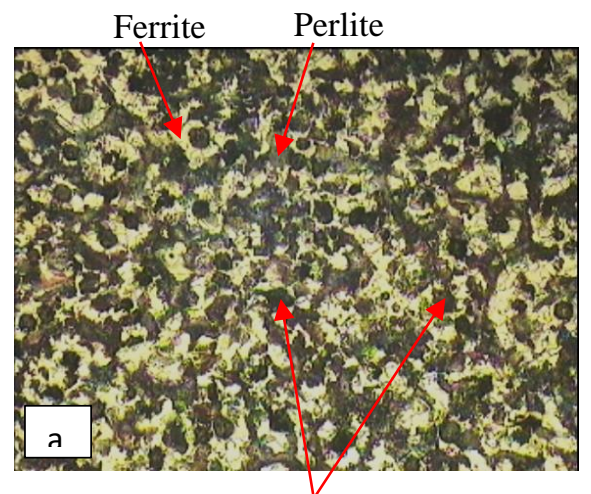

Graphite
Ferritic halo around graphite

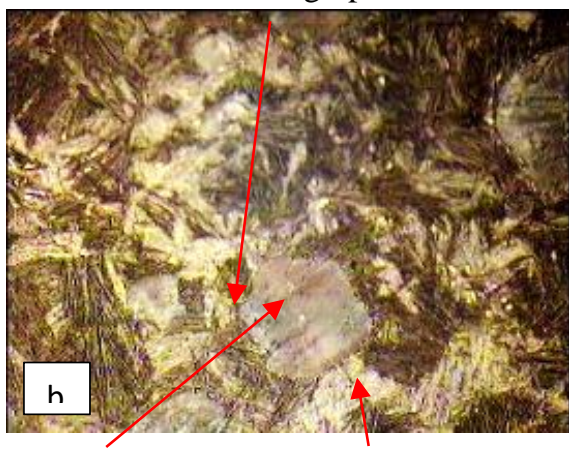

Globular
Retained

Figure 3 Microstructure of a) as cast DI at 100X magnification, b) austempered DI 100X magnification

Table 3 Measured vertical cutting force during drilling of the $16 \mathrm{MnCr} 5$ under different cutting conditions

\begin{tabular}{cccc}
\hline Run & $\mathbf{n}(\mathbf{r p m})$ & $\mathbf{f}(\mathbf{m m} / \mathbf{m i n})$ & $\mathbf{F}(\mathbf{N})$ \\
\hline 1 & 400 & 100 & 3695 \\
2 & 400 & 125 & 4238 \\
3 & 400 & 160 & 4851 \\
4 & 500 & 100 & 3235 \\
5 & 500 & 125 & 3792 \\
6 & 500 & 160 & 4368 \\
7 & 600 & 100 & 2729 \\
8 & 600 & 125 & 3340 \\
9 & 600 & 160 & 3919 \\
\hline
\end{tabular}

Table 4 Measured vertical cutting force during drilling of the DI under different cutting conditions

\begin{tabular}{cccc}
\hline Run & $\mathbf{n}(\mathbf{r p m})$ & $\mathbf{f}(\mathbf{m m} / \mathbf{m i n})$ & $\mathbf{F}(\mathbf{N})$ \\
\hline 1 & 400 & 100 & 5008 \\
2 & 400 & 125 & 5993 \\
3 & 400 & 160 & 7141 \\
4 & 500 & 100 & 3973 \\
5 & 500 & 125 & 4830 \\
6 & 500 & 160 & 6131 \\
7 & 600 & 100 & 3214 \\
8 & 600 & 125 & 4020 \\
9 & 600 & 160 & 5278 \\
\hline
\end{tabular}

Table 5 Analysis of variance on thrust force drilling of $16 \mathrm{MnCr} 5$

\begin{tabular}{lrrrrrr}
\hline Source & DF & Seq SS & Adj SS & Adj MS & F & P \\
\hline $\mathrm{n}(\mathrm{rpm})$ & 2 & 1302954 & 1302954 & 651477 & 1542.57 & $<0.05$ \\
$\mathrm{f}(\mathrm{mm} / \mathrm{min})$ & 2 & 2017421 & 2017421 & 1008710 & 2388.42 & $<0.05$ \\
Residual Error & 4 & 1689 & 1689 & 422 & & \\
Total & 8 & 3322064 & & & & \\
\hline
\end{tabular}


Table 6 Analysis of variance on thrust force drilling of DI

\begin{tabular}{lrrrrrr}
\hline Source & DF & Seq SS & Adj SS & Adj MS & F & P \\
\hline $\mathrm{n}(\mathrm{rpm})$ & 2 & 5317139 & 5317139 & 2658569 & 932.78 & $<0.05$ \\
$\mathrm{f}(\mathrm{mm} / \mathrm{min})$ & 2 & 6793309 & 6793309 & 3396654 & 1191.74 & $<0.05$ \\
Residual Error & 4 & 11401 & 11401 & 2850 & & \\
Total & 8 & 12121848 & & & & \\
\hline
\end{tabular}

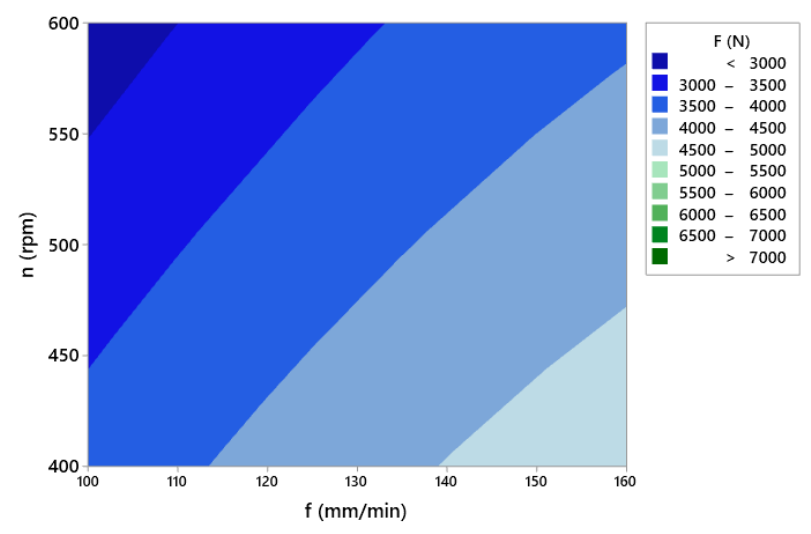

(a)

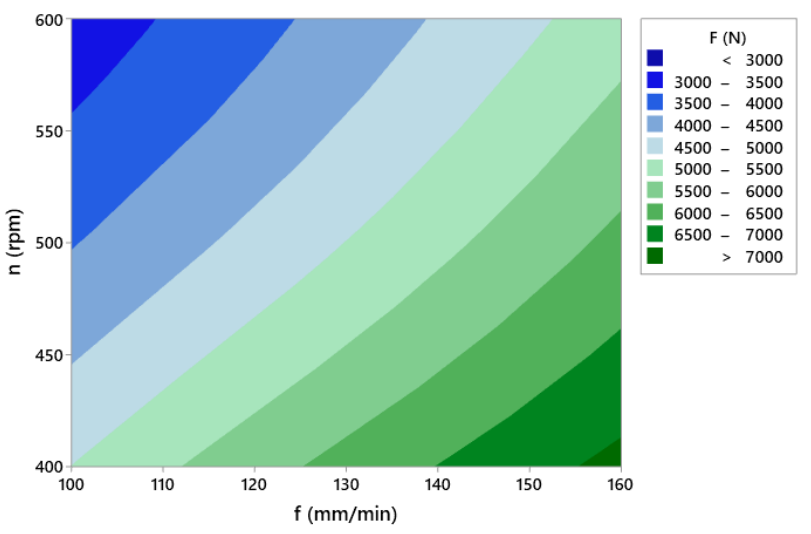

(b)

Figure 4 Contour plot of thrust force vs. $n$ and $f,(a) 16 \mathrm{MnCr} 5,(b) \mathrm{DI}$

Table 7 estimated machinability rating

\begin{tabular}{|c|c|c|c|c|c|}
\hline \multicolumn{2}{|c|}{$\mathrm{n}(\mathrm{rpm})$} & 400 & 400 & 600 & 600 \\
\hline \multicolumn{2}{|c|}{$\mathrm{f}(\mathrm{mm} / \mathrm{min})$} & 100 & 160 & 100 & 160 \\
\hline Predicted & $16 \mathrm{MnCr} 5$ & 3686 & 4851 & 2741 & 3907 \\
\hline $\mathrm{F}(\mathrm{N})$ & DI & 5054 & 7185 & 3170 & 5300 \\
\hline \multicolumn{2}{|c|}{ Force Ratio (\%) } & 73 & 68 & 86 & 74 \\
\hline \multirow{2}{*}{$\begin{array}{l}\text { Machinability } \\
\text { rating }(\%)\end{array}$} & $16 \mathrm{MnCr} 5$ & 74 & 57 & 100 & 70 \\
\hline & DI & 54 & 38 & 86 & 52 \\
\hline
\end{tabular}

\section{Discussion}

As mentioned in the previous section, at a lower feed rate, the thrust load acting on the drilling tool is very close for both materials, such that the estimated machinability rating is $86 \%$. These findings are in good agreement with the literature, where the results have shown that increase in the cutting force as the feed rate increased $[15,16]$. The mentioned phenomenon is more pronounced in ductile iron and is addressed due to strain-induced transformation of austenite to martensite at the cutting surface. Considering this issue, it is recommended to machined ADI at 25\% lower cutting speeds than conventional steels with comparable bulk hardness [17].

\section{Conclusions}

In this study, the machinability of alloyed ductile iron to produce ADI components was compared with forged alloy steels. Thrust force during drilling operation was measured and used to evaluate 
the machinability rating. The results of the tests indicated that at lower feed rate, the machinability of the alloy cast iron is nearly identical in comparison with normalized forged steel, despite its higher hardness.

The obtained results indicate that the required mechanical property of Ring Gear, currently made in normalized forged $16 \mathrm{MnCr} 5$, can be satisfied by using austempered ductile iron.

\section{Acknowledgments}

The author is grateful to Iran Tractor Manufacturing Company (ITM Co.), for the support of this research and the provision of laboratory facilities.

\section{References}

[1] Harding RA. The production , properties and automotive applications of austempered ductile iron. Kov Mater 2007;45:1-16.

[2] Hayrynen KL, Keough JR. Austempered Ductile Iron-The State of the Industry in 2003. Keith Millis Symp. Ductile Cast Iron, 2003.

[3] Bahmani M, Elliott R, Varahram N, Bahmani M, Elliott R, Varahramt N. Austempered ductile iron : a competitive alternative for forged induction-hardened steel crankshafts. Int J Cast Met Res 1997:249-57. doi:10.1080/13640461.1997.11819666.

[4] Rao L, Tao W, Wang S, Geng M, Cheng G. Influence of the composition ratio of manganese and copper on the mechanical properties and the machining performance of ductile iron. Indian J Eng Mater Sci 2014;21:573-9.

[5] Hasirci H. Evaluation of machinability of austempered ductile irons in terms of cutting forces and surface quality. J Mater Process Tech 2006;173:260-8. doi:10.1016/j.jmatprotec.2005.05.058.

[6] Putatunda SK. Comparison of the mechanical properties of austempered ductile cast iron (ADI) processed by conventional and step-down austempering process. Mater Manuf Process 2010;25:749-57.

[7] Sohi MH, Ahmadabadi MN, Vahdat AB. The role of austempering parameters on the structure and mechanical properties of heavy section ADI. J Mater Process Technol 2004;153:203-8.

[8] Kim Y-J, Shin H, Park H, Lim JD. Investigation into mechanical properties of austempered ductile cast iron (ADI) in accordance with austempering temperature. Mater Lett 2008;62:357-60.

[9] Refaey A, Fatahalla N. Effect of microstructure on properties of ADI and low alloyed ductile iron. J Mater Sci 2003;38:351-62.

[10] Lerner YS, Kingsbury GR. Wear resistance properties of austempered ductile iron. J Mater Eng Perform 1997;7:48-52.

[11] Cakir MC. Investigating the machinability of austempered ductile irons having different austempering temperatures and times. Mater Des 2008;29:937-42. doi:10.1016/j.matdes.2007.04.002.

[12] Tanabi H, Babaei N, Babaei A. Real-time tool wear monitoring based on feed motor current in chuck-center mounting condition. vol. 341-342. 2012. doi:10.4028/www.scientific.net/AMR.341-342.307.

[13] Polishetty A. Machinability and microstructural studies on phase transformations in Austempered Ductile Iron. Auckland University of Technology, 2012.

[14] Brandenberg K. Successfully Machining Austempered Ductile Iron ( ADI ). 2001.

[15] Polishetty A, Littlefair G, Pasang T. A Case Study on Effect of Feed Rate on Machinability of Austempered Ductile Iron 2013;748:247-51. doi:10.4028/www.scientific.net/AMR.748.247.

[16] Fernanda N, Pereira S, Carlos J, Rubio C, Júnior A, Houmard M, et al. Drilling of nodular cast iron with a novel $\mathrm{SiO} 2$ coating deposited by sol-gel process in HSS drill 2019.

[17] Handayani D, Voigt RC, Hayrynen K. Understanding the Machinability of Austempered Ductile Iron (ADI). Mater Sci Forum 2018;925:311-7. doi:10.4028/www.scientific.net/MSF.925.311. 